\title{
Effect of rice husk biochar, carpet waste, farm yard manure and plant growth promoting rhizobium on the growth and yield of rice (Oryza sativa)
}

\author{
D. K. Singhal ${ }^{1}$, JanardanYadav ${ }^{2}$, Shiv Singh Meena ${ }^{3 *}$, Divyesh Chandra Kala ${ }^{4}$ \\ ${ }^{1,2,3}$ Department of Soil Science and Agricultural Chemistr, Banaras Hindu University, Varanasi (U.P.), INDIA \\ ${ }^{4}$ Department of Soil Science, College of Agriculture, GBPUA \&T, Pantnagar, U. S. Nagar (Uttarakhand), INDIA \\ *Corresponding author. E-mail-meenashiva20@gmail.com
}

Received: November 22, 2016; Revised received: April 17, 2017; Accepted: September 20, 2017

\begin{abstract}
The present investigation was aimed for improving growth and yield of crop using waste products of different activities and also useful in ecological stability of soil environment. This objective is not only an economic option for poor farmer but also an effective strategy for increasing yield. The experiment was conducted in the organic farming plot of the Institute of Agricultural Sciences, BHU,Varanasi during kharif season of rice crop in 2014. The field experiment was laid out in randomized block design (RBD) with 10 treatments and three replications. Application of graded level of biochar, carpet waste farm yard manure (FYM) and plant growth promoting rhizobium (PGPR) was found to significantly enhance the grain andstraw yield of rice by $57.70 \%$ and $56.08 \%$ over control, respectively.
\end{abstract}

Keywords: Carpet waste, FYM, PGPR, Rice, Rice husk biochar

\section{INTRODUCTION}

Rice is the staple food for over half the world's population. Approximately 480 million metric tons of milled rice is produced annually. China and India alone account for approximate $50 \%$ of the rice grown and consumed (Muthayya et al., 2014). In India, it occupies43.86 million ha of land and produces about 104.80 million tons ofgrain with the productivity of 2.39tones $\mathrm{ha}^{-1}$ (Anonymous, 2015).However, this is not enough to feed the ever-increasing population, and there is need to increase the production to keep pace with population growth.

Biochar is carbon rich solid product obtained after heating biomass, such as wood, manure or leaves under limited supply or absence of oxygen. Biochar application has received a growing interest as a sustainable technology to improve highly weathered or degraded tropical soils (Lehmann and Rondon, 2006). Biochar application can enhance plant growth by improving soil chemical characteristics (i.e. nutrient retention, nutrient availability), soil physical characteristics (i.e. bulk density, water holding capacity, permeability), and soil biological properties, all contributing to an increased crop productivity (Lehmann and Rondon, 2006; Yamato et al., 2006). In addition, biochar is highly recalcitrant to microbial decomposition and thus guarantees a long term benefit for soil fertility (Steiner et al., 2007). Biochar has a fantastic quality of absorbance and when applied in soil, it absorb moisture, plant nutrient, agricultural chemicals and thereby reduce loss of nutrients through leaching and surface runoff of water. Biochar is a relatively low density material that helps in lowering the bulk density in heavy texture soil along with increase in aeration and root penetration and thus the water holding capacity. These actual effects of biochar application, however, depend on various factors such as the soil fertility and the water balance at a given site, and possibly even the cultivated genotype.

Farmyard manure is easily available, cheap, proven source of nutrition and has been traditionally used by farmers (Nanda et al., 2016).PGPR consists of a diverse type of rhizobacteria known to stimulate plant growth directly either by synthesizing hormones such as indole acetic acid or by promoting nutrition, by phosphate solubilisation or generally by accelerating mineralization process. They can also stimulate growth indirectly by acting as bio control agent by protecting the plant against soil born fungal pathogens or deleterious bacteria. Some PGPR suppress pathogen by synthesizing antifungal metabolites (Vassilev etal., 2006). Application of FYM along with PGPR improved organic carbon, available $\mathrm{N}, \mathrm{P}$ and $\mathrm{K}$ content in soil when applied in mung bean (Das and Singh, 2014).Positive interaction between biochar and PGPR resulted in improved growth attributes and biomass yield in switch grass (Shanta, 2012).

Waste products like biochar, Carpet waste, etc.can be important for improving crop

growth and yield and also in the waste management. Organic carbon pools in Indian soils is declining due to heavy and imbalanced incorporation of chemical fertilizers and ignorance or unavailability or inaccessibility 
of the organic matter. Considering all these facts in Indian context there is a need to study the combined effect of Biochar, FYM, Carpet waste and PGPR as a source of organic material to soil.

\section{MATERIALS AND METHODS}

The experiment was carried out at the Organic farming plot of the Institute of Agricultural Sciences, BHU, Varanasi.Three replications of each treatment were maintained in the experiment. So there were 27 experimental plots along with three control plots (without any treatment). The experiment was conducted in Randomized Block Design. To determine the initialphysico -chemical properties of soil representative soil samples were collected from five different places before conducting the experiment from the depth of $0-20 \mathrm{~cm}$ in sandy clay loam texture soil with $\mathrm{pH}$ value of 7.42 , EC - $0.170 \mathrm{dSm}^{-1}$ and organic carbon $0.45 \%$. The initial soil was low in available $\mathrm{N}\left(258.55 \mathrm{~kg} \mathrm{ha}^{-1}\right)$, medium in available $\mathrm{P}\left(14.27 \mathrm{~kg} \mathrm{ha}^{-1}\right)$ and medium in available $\mathrm{K}\left(223.45 \mathrm{~kg} \mathrm{ha}^{-1}\right)$.Pre-Prepared Biochar was collected from Shree ram rice mill jasuri, Chandauli, Uttar Pradesh in the month of June 2014.

\section{RESULTS AND DISCUSSION}

Effect of treatment on growth of rice

Effect on plant height of rice: The data pertaining to effect of biochar and PGPR on height of plant is presented in table 1. It is evident from the table that height of plant (30 DAT) varied from 77.5 to 98.6. It was higher in treatment $\mathrm{T}_{10}\left(\mathrm{BC}_{2}+\mathrm{CW}_{1}+\mathrm{FYM}_{1} \mathrm{tha}^{-1}+\right.$ PGPR $) 98.6 \mathrm{~cm}$ followed by $\mathrm{T}_{9}\left(\mathrm{BC}_{1}+\mathrm{CW}_{1}+\mathrm{FYM}_{1} \mathrm{t}\right.$ $\mathrm{ha}^{-1}+$ PGPR) $98.1 \mathrm{~cm}$. Significant differences were found between the treatments after application of PGPR in the plot. The inoculation with PGPR showed significantly higher plant height $(98.6 \mathrm{~cm})$ at 30 DAT than uninoculated treatment $(84.1 \mathrm{~cm})$. The treatment $\mathrm{T}_{7}\left(\mathrm{BC}_{1}+\mathrm{CW}_{1} \mathrm{tha}^{-1}+\mathrm{PGPR}\right)$ was found $90.9 \mathrm{~cm}$ plantheightfollowed by $\mathrm{T}_{2}\left(\mathrm{BC}_{1}+\mathrm{CW}_{1} \mathrm{t} \mathrm{ha}^{-1}\right) 80.7 \mathrm{~cm}$ and treatment $\mathrm{T}_{6}(\mathrm{PGPR})$ was found $87.0 \mathrm{~cm}$ followed by $\mathrm{T}_{1}$ (control) $77.5 \mathrm{~cm}$. However, the treatment $\mathrm{T}_{2}\left(\mathrm{BC}_{1}+\right.$ $\left.\mathrm{CW}_{1} \mathrm{tha}^{-1}\right), \mathrm{T}_{3}\left(\mathrm{BC}_{2}+\mathrm{CW}_{1} \mathrm{tha}^{-1}\right)$ and $\mathrm{T}_{9}\left(\mathrm{BC}_{1}+\mathrm{CW}_{1}\right.$ $+\mathrm{FYM}_{1} \mathrm{tha}^{-1}+$ PGPR $), \mathrm{T}_{10}\left(\mathrm{BC}_{2}+\mathrm{CW}_{1}+\mathrm{FYM}_{1} \mathrm{tha}^{-1}\right.$ + PGPR) were found statically at par to each other. Almost similar trend was noticed with the plant height recorded at $60 \mathrm{DAT}$.

Mathivananet al. (2005) reported that application of PGPR significantly increased the plant height over control. The increase in plant height may be attributed due to adequate supply of nutrients by the PGPR. Abbasi et al. (2011) have also reported that inoculation of PGPR in wheat increase shoot length by $25 \%$ over the un-inoculated control.

Effect on chlorophyll content: Data pertaining to the chlorophyll content (SPAD value) in leaf as influenced by biochar, carpet waste, FYM and PGPR application is give in table 1. There was a significant increase in chlorophyll content at 30 DAT with the application of biochar, carpet waste, FYM and PGPR. The maximum chlorophyll content (36.2) in leaf was found in treatment $\mathrm{T}_{10}\left(\mathrm{BC}_{2}+\right.$ $\left.\mathrm{CW}_{1}+\mathrm{FYM}_{1} \mathrm{tha}^{-1}+\mathrm{PGPR}\right)$ followed by $\mathrm{T}_{9}\left(\mathrm{BC}_{1}+\right.$ $\left.\mathrm{CW}_{1}+\mathrm{FYM}_{1} \mathrm{t} \mathrm{ha}^{-1}+\mathrm{PGPR}\right)$. The minimum chlorophyll content (26.5) was found in treatment $T_{1}$ (control). The application of biochar and carpet waste in treatment $\mathrm{T}_{2}\left(\mathrm{BC}_{1} \& \mathrm{CW}_{1}\right)$ increase chlorophyll content $1.50 \%$ over the control,while $\mathrm{T}_{6}$ (PGPR) increased 2.64\%, and $\mathrm{T}_{10}\left(\mathrm{BC}_{2}+\mathrm{CW}_{1}+\right.$ $\left.\mathrm{FYM}_{1} \mathrm{t} \mathrm{ha}^{-1}+\mathrm{PGPR}\right)$ increased $36.60 \%$.Decrease in chlorophyll content (leaf SPAD value) with biochar has been reported by Asai et al. (2009) in rice, possibly due to reduction in the availability of soil nitrogen to the plant because of its high $\mathrm{C}: \mathrm{N}$ ratio. The inoculation with PGPR showed significantly higher chlorophyll content (36.2) than without its inoculation (27.5). The increase in chlorophyll content may be attributed to adequate supply of nitrogen by carpet waste and PGPR. Almost similar trend was observed in chlorophyll content recorded at 60 DAT.

Effect on number of tillers per hill: A critical perusal of the data presented in Table 1 revealed that a significant increase was found in number of tillers at 30 DAT with the application ofBC, CW FYM \& PGPR. Application of PGPR and different doses of biochar resulted significant increase in number of tillers (30 DAT). The maximum number of tillers (28.3) was noted in $\mathrm{T}_{10}$ $\left(\mathrm{BC}_{2}+\mathrm{CW}_{1}+\mathrm{FYM}_{1} \mathrm{t} \mathrm{ha}^{-1}+\mathrm{PGPR}\right)$ and minimum number of tillers (14.2) in $\mathrm{T}_{1}$ (control) at $30 \mathrm{DAT}$. The application of biochar and carpet waste in treatment $\mathrm{T}_{2}$ $\left(\mathrm{BC}_{1}+\mathrm{CW}_{1} \mathrm{t} \mathrm{ha}^{-1}\right)$ increases number of tillers $13.38 \%$ over the control, while $\mathrm{T}_{6}(\mathrm{PGPR})$ increased $69.01 \%, \mathrm{~T}_{4}$ $\left(\mathrm{BC}_{1}+\mathrm{CW}_{1}+\mathrm{FYM}_{1} \mathrm{tha}^{-1}\right)$ increased $71.83 \%$ and $\mathrm{T}_{10}$ $\left(\mathrm{BC}_{2}+\mathrm{CW}_{1}+\mathrm{FYM}_{1} \mathrm{t} \mathrm{ha}^{-1}+\mathrm{PGPR}\right)$ increased 99.29\%.However, the treatment $\mathrm{T}_{2}\left(\mathrm{BC}_{1}+\mathrm{CW}_{1} \mathrm{tha}^{-1}\right)$, $\mathrm{T}_{3}\left(\mathrm{BC}_{2}+\mathrm{CW}_{1} \mathrm{tha}^{-1}\right)$ and $\mathrm{T}_{9}\left(\mathrm{BC}_{1}+\mathrm{CW}_{1}+\mathrm{FYM}_{1} \mathrm{t}\right.$ ha ${ }^{1}+$ PGPR $)$ and $\mathrm{T}_{10}\left(\mathrm{BC}_{2}+\mathrm{CW}_{1}+\mathrm{FYM}_{1} \mathrm{t} \mathrm{ha}^{-1}+\mathrm{PGPR}\right)$

Table 1. Details of treatments followed in the plot.

\begin{tabular}{ll}
\hline $\begin{array}{l}\text { Treat- } \\
\text { ments }\end{array}$ & Details of treatments \\
\hline $\mathrm{T}_{1}$ & Control \\
$\mathrm{T}_{2}$ & Biochar + carpet waste $(1+1 \mathrm{t}) \mathrm{ha}^{-1}$ \\
$\mathrm{~T}_{3}$ & Biochar + carpet waste $(2+1 \mathrm{t}) \mathrm{ha}^{-1}$ \\
$\mathrm{~T}_{4}$ & Biochar + carpet waste $+\mathrm{FYM}(1+1+1 \mathrm{t}) \mathrm{ha}^{-1}$ \\
$\mathrm{~T}_{5}$ & Biochar + carpet waste $+\mathrm{FYM}(2+1+1 \mathrm{t}) \mathrm{ha}^{-1}$ \\
$\mathrm{~T}_{6}$ & PGPR \\
$\mathrm{T}_{7}$ & Biochar + carpet waste $(1+1 \mathrm{t}) \mathrm{ha}^{-1}+\mathrm{PGPR}^{-1}$ \\
$\mathrm{~T}_{8}$ & Biochar + carpet waste $(2+1 \mathrm{t}) \mathrm{ha}^{-1}+\mathrm{PGPR}$ \\
$\mathrm{T}_{9}$ & Biochar + carpet waste+FYM $(1+1+1 \mathrm{t}) \mathrm{ha}^{-1}+$ \\
& PGPR \\
$\mathrm{T}_{10}$ & Biochar + carpet waste $+\mathrm{FYM}(2+1+1 \mathrm{t}) \mathrm{ha}^{-1}+$ \\
& PGPR \\
\hline
\end{tabular}

PGPR: Plant Growth Promoting Rhizobacteria (Rhizobium + Azotobacterchroococcum HUAZ-1 +Pseudomonas fluoreseans BHUPSB-06 + Paenibacilluspolymyxa BHUPSB- 
D. K. Singhal et al. / J. Appl. \& Nat. Sci. 9 (4): 2043 -2046 (2017)

Table 2. Effect of biochar, carpet waste, FYM and PGPR consortium on plant growth of rice at different intervals.

\begin{tabular}{|c|c|c|c|c|c|c|}
\hline & 30 DAT & & & $60 \mathrm{DAT}$ & & \\
\hline Treatment & $\begin{array}{l}\text { Height plant } \\
\text { (cm) }\end{array}$ & $\begin{array}{l}\text { Chlorophyll } \\
\text { content } \\
\text { ( SPAD val- } \\
\text { ue ) }\end{array}$ & $\begin{array}{l}\text { No. of tillers } \\
\text { hill }^{-1}\end{array}$ & $\begin{array}{l}\text { Height plant } \\
\text { (cm) }\end{array}$ & $\begin{array}{l}\text { Chlorophyll } \\
\text { content } \\
\text { ( SPAD val- } \\
\text { ue ) }\end{array}$ & $\begin{array}{l}\text { No. of tillers } \\
\text { hill }^{-1}\end{array}$ \\
\hline $\mathrm{T}_{1}$ & 77.5 & 26.5 & 14.2 & 94.7 & 25.4 & 19.7 \\
\hline $\mathrm{T}_{2}$ & 80.7 & 26.9 & 16.1 & 96.8 & 25.5 & 25.6 \\
\hline $\mathrm{T}_{3}$ & 82.5 & 27.6 & 19.2 & 96.9 & 25.4 & 27.2 \\
\hline $\mathrm{T}_{4}$ & 87.9 & 29.5 & 24.4 & 101.4 & 29.4 & 30.6 \\
\hline $\mathrm{T}_{5}$ & 84.1 & 27.5 & 23.2 & 98.4 & 25.0 & 26.4 \\
\hline $\mathrm{T}_{6}$ & 87.0 & 27.2 & 24.0 & 106.2 & 26.8 & 28.6 \\
\hline $\mathrm{T}_{7}$ & 90.9 & 29.5 & 25.2 & 107.3 & 27.5 & 30.7 \\
\hline $\mathrm{T}_{8}$ & 94.4 & 29.0 & 27.4 & 106.5 & 26.3 & 32.5 \\
\hline $\mathrm{T}_{9}$ & 98.1 & 30.7 & 27.8 & 111.6 & 30.5 & 34.4 \\
\hline $\mathrm{T}_{10}$ & 98.6 & 36.2 & 28.3 & 116.4 & 33.2 & 36.3 \\
\hline $\mathrm{SEm} \pm$ & 4.089 & 1.373 & 1.315 & 3.991 & 1.275 & 1.669 \\
\hline $\mathrm{CD}$ at $5 \%$ & 11.826 & 3.972 & 3.805 & 11.543 & 3.689 & 4.827 \\
\hline
\end{tabular}

Table 3. Effect of biochar, carpet waste, FYM and PGPR consortium grain and straw yield of rice at harvesting stage.

\begin{tabular}{|c|c|c|c|}
\hline \multicolumn{2}{|c|}{ Treatment } & \multirow{2}{*}{$\begin{array}{l}\text { Grain yield }\left(\mathrm{q} \mathrm{ha}^{-1}\right) \\
22.7\end{array}$} & \multirow{2}{*}{$\begin{array}{l}\text { Straw yield }\left(\mathbf{q} \text { ha }^{-1}\right) \\
33.7\end{array}$} \\
\hline $\mathrm{T}_{1}$ & Control & & \\
\hline $\mathrm{T}_{2}$ & Biochar+ carpet waste $(1+1 \mathrm{t}) \mathrm{ha}^{-1}$ & 24.5 & 36.4 \\
\hline $\mathrm{T}_{3}$ & Biochar + carpet waste $(2+1 \mathrm{t}) \mathrm{ha}^{-1}$ & 25.8 & 38.5 \\
\hline $\mathrm{T}_{4}$ & Biochar + carpet waste + FYM $(1+1+1 \mathrm{t}) \mathrm{ha}^{-1}$ & 29.4 & 42.4 \\
\hline $\mathrm{T}_{5}$ & Biochar + carpet waste $+\mathrm{FYM}(2+1+1 \mathrm{t}) \mathrm{ha}^{-1}$ & 31.2 & 44.7 \\
\hline $\mathrm{T}_{6}$ & PGPR & 24.3 & 36.8 \\
\hline $\mathrm{T}_{7}$ & Biochar + carpet waste $(1+1 \mathrm{t}) \mathrm{ha}^{-1}+\mathrm{PGPR}$ & 26.7 & 39.3 \\
\hline $\mathrm{T}_{8}$ & Biochar + carpet waste $(2+1 \mathrm{t}) \mathrm{ha}^{-1}+\mathrm{PGPR}$ & 27.9 & 41.8 \\
\hline $\mathrm{T}_{9}$ & Biochar + carpet waste + FYM $(1+1+1$ t $)$ ha $^{-1}+$ PGPR & 33.6 & 48.4 \\
\hline & Biochar + carpet waste $+\mathrm{FYM}(2+1+1 \mathrm{t}) \mathrm{ha}^{-1}+\mathrm{PGPR}$ & 35.8 & 52.6 \\
\hline \multicolumn{2}{|c|}{ SEm \pm} & 1.515 & 2.218 \\
\hline \multicolumn{2}{|c|}{$\mathrm{CD}$ at $5 \%$} & 4.383 & 6.415 \\
\hline
\end{tabular}

were found statically at par to each other.The inoculation with PGPR showed significantly higher number of tillers (28.3) at 30 DAT than without its inoculation (23.2). Almost similar trend was noticed with the number of tillers recorded at 60 DAT.Inoculation with PGPR increase the number of tillers in wheat was reported by Zahir et al. (2003) and Cakmakci et al. (2001).

Effect of biochar, carpet waste, FYM and PGPR on grain and straw yield of rice at harvest

Effect on grain yield: A critical perusal of the data presented in table 2 revealed that the grain yield of rice was ranging from $22.7 \mathrm{qha}^{-1}$ to $35.8 \mathrm{qha}^{-1}$ and it has increased significantly with the application of graded levels ofBC, CW, FYM\& PGPR. The maximum grain yield $\left(35.8 \mathrm{qha}^{-1}\right)$ was recorded in the treatment $\mathrm{T}_{10}\left(\mathrm{BC}_{2}+\mathrm{CW}_{1}+\mathrm{FYM}_{1} \mathrm{tha}^{-1}+\mathrm{PGPR}\right)$ which were $14.74 \%$ higher than treatment $\mathrm{T}_{5}\left(\mathrm{BC}_{2}+\mathrm{CW}_{1}+\right.$ $\left.\mathrm{FYM}_{1} \mathrm{tha}^{-1}\right)$. The treatment $\mathrm{T}_{10}\left(\mathrm{BC}_{2}+\mathrm{CW}_{1}+\mathrm{FYM}_{1} \mathrm{t}\right.$ $\mathrm{ha}^{-1}+$ PGPR) was found $57.70 \%$ higher over the treatment $\mathrm{T}_{1}$ (control). The treatment $\mathrm{T}_{7}\left(\mathrm{BC}_{1}+\mathrm{CW}_{1} \mathrm{t} \mathrm{ha}^{-1}+\right.$ PGPR) gave 26.7 qha $^{-1}$ grain yield which was $8.97 \%$ higher over the $\mathrm{T}_{2}\left(\mathrm{BC}_{1}+\mathrm{CW}_{1} \mathrm{t} \mathrm{ha}^{-1}\right)$. Treatment $\mathrm{T}_{6}$ (PGPR) gave $7.04 \%$ higher grain yield over the $T_{1}$ (control).However, the treatment $\mathrm{T}_{2}\left(\mathrm{BC}_{1}+\mathrm{CW}_{1} \mathrm{t}\right.$ ha $\left.{ }^{1}\right), \mathrm{T}_{3}\left(\mathrm{BC}_{2}+\mathrm{CW}_{1} \mathrm{tha}^{-1}\right)$ and $\mathrm{T}_{9}\left(\mathrm{BC}_{1}+\mathrm{CW}_{1}+\mathrm{FYM}_{1} \mathrm{t}\right.$ $\mathrm{ha}^{-1}+$ PGPR), $\mathrm{T}_{10}\left(\mathrm{BC}_{2}+\mathrm{CW}_{1}+\mathrm{FYM}_{1} \mathrm{tha}^{-1}+\right.$ PGPR $)$ were found statically at par to each other.

Rondon et al., (2007) reported that bean yield increased by $46 \%$ and biomass production by $39 \%$ over the control at application of $60 \mathrm{~g}$ biochar per $\mathrm{kg}$ soil. Thakuria et al. (2004) reported that inoculation of different PGPR can increase rice yield from 10 to $76 \%$ over control in which Pseudomonas aeruginosa and $P$. fluorescenscan increase rice yield by $49.2 \%$ and $23.01 \%$ respectively, over control.

Effect on straw yield: A critical perusal of the data presented in table 2 revealed that the application of $\mathrm{BC}_{2}+\mathrm{CW}_{1}+\mathrm{FYM}_{1} \mathrm{tha}^{-1}+\mathrm{PGPR}$ resulted in significantly higher straw yield by $56.08 \%$ than the straw yield obtained from the treatment $\mathrm{T}_{1}$ (control). The maximum straw yield (52.60 qha 1 ) was recorded in the treatment $\mathrm{T}_{10}\left(\mathrm{BC}_{2}+\mathrm{CW}_{1}+\mathrm{FYM}_{1} \mathrm{t} \mathrm{ha}^{-1}+\mathrm{PGPR}\right)$ which were $17.67 \%$ higher than treatment $\mathrm{T}_{5}\left(\mathrm{BC}_{2}+\right.$ $\left.\mathrm{CW}_{1}+\mathrm{FYM}_{1} \mathrm{tha}^{-1}\right)$. The treatment $\mathrm{T}_{7}\left(\mathrm{BC}_{1}+\mathrm{CW}_{1} \mathrm{t}\right.$ ha $\left.{ }^{1}+\mathrm{PGPR}\right)$ gave39.30 $\mathrm{q} \mathrm{ha}^{-1}$ straw yield which was $7.96 \%$ higher over the $\mathrm{T}_{2}\left(\mathrm{BC}_{1}+\mathrm{CW}_{1} \mathrm{tha}^{-1}\right)$. Treatment $\mathrm{T}_{6}$ (PGPR) gave $9.19 \%$ higher over $\mathrm{T}_{1}$ (control). Increase in the chlorophyll content in leaf thus increased the photosynthesis rate and ultimately photosynthetic products increased the biomass of plant. Significant increase in straw yield was might be due to the availa- 
bility of all essential elements to the rice crop in sufficient amount by the FYM, carpet waste and PGPR application.Das and Saha (2005) have found an increase in rice yield by $23.7 \%$ due to combined inoculation of Azotobacter strain $\mathrm{DS}_{3}+$ Azospirillum strain $\mathrm{DM}_{10}$.

\section{Conclusion}

Application of graded level of biochar, carpet waste FYM and PGPR was found to significantly effective to enhance the grain and straw yield of rice. Application of biochar + carpet waste + FYM $(2+1+1 \mathrm{t}) \mathrm{ha}^{-1} \&$ PGPR was found $57.70 \%$ higher over the treatment $\mathrm{T}_{1}$ (control). Application of PGPR consortium (Azospirillium + Azotobacterchroococcum HUAZ-1 + Paenibacilluspolymyxa BHUPSB-16) $\left(\mathrm{T}_{6}\right)$ enhanced maximum grain yield $35.8 \mathrm{q} \mathrm{ha}^{-1}$ which $7.04 \%$ higher over the $\mathrm{T}_{1}$ (control). Application of $\mathrm{BC}_{2}+\mathrm{CW}_{1}+$ $\mathrm{FYM}_{1} \mathrm{t} \mathrm{ha}^{-1}+$ PGPR resulted in significantly higher straw yield (52.6 q ha ${ }^{-1}$ )which was56.08\% than the straw yield obtained from the treatment $\mathrm{T}_{1}$ (control). Application of PGPR $\left(\mathrm{T}_{6}\right)$ was found $9.19 \%$ higher over the $\mathrm{T}_{1}$ (control).

\section{REFERENCES}

Abbasi, M.K., Sharif, S., Kajmi, M., Sultan, T. and Aslam, M. (2011). Isolation of plant growth promoting rhizobacteria from wheat rhizosphere and their effect on improving growth, yield and nutrient uptake of plant. Plant Biosystems, 145 (1), 159-168.

Anonymous. (2015). Agricultural Statistics Division, Directorate of Economics \& Statistics, Department of Agriculture \& Cooperation.

Asai, H., Samson, B.K., Stephan, H.M., Songyikhangsuthor, K., Homma, K., Kiyono, Y., Inoue, Y., Shiraiwa, T. and Horie, T. (2009). Biochar amendment techniques for uplandrice production in northern Laos.Field Crops Res, 111, 81-84.

Cakmakci, R., Kantar, F. and Sahin, F. (2001). Effect of $\mathrm{N}_{2}-$ fixing bacterial inoculations on yield of sugar beet and barley.J. Plant Nutr. Soil Sci., 164, 527-531.

Das, A.C. and Saha, D. (2005). Non symbiotic nitrogen fixing bacteria influencing mineral and hydrolysable organic nitrogen in rhizosphere soil of rice (Oryzasativa). Indian Journal of Agricultural Sciences, 75 (5), 265 269.

Das, I. and Singh, A. P. (2014).Effect of PGPR and organic manures on soil propertiesof organically cultivated mungbean. The Bioscan9, 27-29.
Lehmann, J., Gaunt, J. and Rondon, M. (2006).Bio-char sequestration in terrestrial ecosystems - a review.Mitigation and Adaptation Strategies for Global Change, 11, 403-427.

Mathivanan, N., Prabavathy, V.R. and Vijayanandraj, V.R. (2005).Application of talc formulations of Pseudomonas fluoresens Migula and Trichoderma viride pers. Ex S.F. Gray disease the sheath blight disease and enhance the plant growth and yield in rice. J. Phytopathology, 153, 679-701.

Muthayya, S., Sugimoto, J. D., Montgomery, S. and Maberly, J. F (2014).An overview of global rice production, supply, trade, and consumption.Annals of the new york Academy of Sciences, 1324, 7-14.

Nanda, G., Meena, R. K., Sravan, U. S. and Singh, S. P. (2016).Effect of NPK levels and bio-organics on yield and nutrient removal of basmati rice cv. HUBR-109.The Bioscan11(1), 555-558.

Rondon, M.A., Lehmann, J., Ramirez, J. and Hurtado, M. (2007). Biological nitrogen fixation by common beans (Phaseolus vulgaris L.) increases with bio-char additions. Biology and Fertility of Soils, 43, 699-708.

Shanta, N. K, (2012). Biochar and PGPR as Methods for Low-input Management of Bioenergy Grasses. M. Sc. Thesis, submitted to McGill University, Macdonald Campus, Quebec, Canada pp.

Steiner, C., Teixeira, W.G., Lehmann, J., Nehls, T., de Macedo, J.L.V., Blum, W.E.H. and Zech, W. (2007) Long term effects of manure, charcoal and mineral fertilization on crop production and fertility on a highly weathered Central Amazonian upland soil. Plant and Soil, 291, 275

Thakuria, D., Talukdar, N.C., Goswami, C., Hazarika, S., Boro, R.C. and Khan, M. R. (2004).Characterization and screening of bacteria from the rhizosphere of rice grown in acidic soils of Assam.Current Sci, 86, 978985.

Vassilev, N., Vassileva, M. and Nikolaeva, I. (2006). Simultaneous P-solubilising and biocontrol activity of microorganisms: potential and future needs.Applied Microbial Biotechnol.71, 137-144.

Yamato, M., Okimori, Y., WibowoI, F., Anshori, S. and Ogawa, M. (2006).Effects of the application of charred bark of Acacia mangium on the yield of maize, cowpea and peanut, and soil chemical properties in South Sumatra, Indonesia.Journal Soil Science and Plant Nutrition, 52, 489-495.

Zahir, Z.A., M. Arshad, and W.T.Jr. Frankenberger (2003).Plant growth promoting rhizobacteria: Applications and perspectives in agriculture. Adv. Agron. 81: 97 -168 . 